\title{
Ketamine versus propofol for strabismus surgery in children
}

This article was published in the following Dove Press journal:

Clinical Ophthalmology

13 July 2010

Number of times this article has been viewed

\author{
Ayse Mizrak' \\ Ibrahim Erbagci² \\ Tulin Arici' \\ Ibrahim Ozcan' \\ Suleyman Ganidagli' \\ Gurkan Tatar ${ }^{2}$ \\ Unsal Oner' \\ 'Anesthesiology and Reanimation, \\ Gaziantep University School \\ of Medicine, Gaziantep, Turkey; \\ ${ }^{2}$ The Department of Ophthalmology, \\ Gaziantep University School of \\ Medicine, Gaziantep, Turkey
}

Purpose: To compare the effects of intravenous infusion of ketamine and propofol anesthesia in children undergoing strabismus surgery.

Methods: Sixty pediatric patients aged 4-11 years were enrolled for the study. Patients in Group K were infused ketamine $1-3 \mathrm{mg} / \mathrm{kg} / \mathrm{hr}(\mathrm{n}=30)$ and patients in Group P were infused with propofol 6-9 mg/kg/hr $(\mathrm{n}=30)$. After giving fentanyl $1 \mu \mathrm{g} / \mathrm{kg}$ and rocuronium bromide $0.5 \mathrm{mg} / \mathrm{kg}$, patients were intubated.

Results: The consumption of anesthetics $(P=0.0001)$ and antiemetics $(P=0.004)$, the incidence of oculocardiac reflex $(P=0.02)$ in Group K were significantly lower than in Group P. The recovery time $(P=0.008)$, postoperative agitation score $(P=0.005)$, Face Pain Scale $(P=0.001)$, Ramsay Sedation Score $(P=0.01)$ during awakening and at postoperative 30th $\min (P=0.02)$ in Group $\mathrm{K}$ were significantly lower than in Group $\mathrm{P}$. The postoperative agitation score during awakening was significantly lower than the preoperative values in Group $\mathrm{K}(P=0.0001)$.

Conclusions: The infusion of ketamine is more advantageous than the infusion of propofol in children for use in strabismus surgery.

Keywords: ketamine, propofol, pediatrics, strabismus, surgery

\section{Introduction}

Strabismus surgery may be associated with significant postoperative pain. Conjunctiva is the main source of this pain. Anxiety induces distress during the procedure, particularly for children who require repeated procedures. ${ }^{2}$ Postoperative nausea and vomiting (PONV) for strabismus surgery ${ }^{3}$ has an incidence of 20\%-30\%. As PONV causes distress for children, it is important to provide safe and effective analgesia. This pain may be treated with opioids, but PONV, which can be a major morbidity factor after strabismus surgery, ${ }^{1}$ may limit their use. Various methods have been used together with antiemetics to diminish PONV. ${ }^{4,5}$ However, there is no consensus on the choice of method. ${ }^{6}$

The incidence of the oculocardiac reflex (OCR) during strabismus has been variously reported as $14 \%$ to $90 \%$, depending on the premedication, anesthetic agent, and the definition of OCR. ${ }^{7}$ OCR occurs through the trigeminovagal reflex arc and can be triggered by mechanical stimulation such as pressure on the eye, intraorbital injections or hematomas and especially by traction on extraocular muscles. ${ }^{8} \mathrm{~A}$ variety of methods such as normoxia, normocapnia, premedication using atropine or glycopyrrolate, and adequate anesthetic depth have been used to prevent the OCR. However, none of them has been found satisfactory. ${ }^{9}$

Propofol and ketamine are sedative and hypnotic anesthetic agents. ${ }^{10,11}$ Propofol has a pharmacokinetic profile leading to rapid induction and recovery times with
Correspondance: Ibrahim Erbagci Gaziantep University Medical Faculty, Department of Ophthalmology, 27310 Sahinbey, Gaziantep, Turkey

Tel +9053243365 I 5

Fax +903423602244

Email ierbagci@yahoo.com 
minimal postoperative confusion. ${ }^{10,12}$ Ketamine anesthesia is associated with the relatively rapid onset of action and fast recovery and least hemodynamic changes induced by OCR during strabismus surgery in pediatric patients. ${ }^{11}$ As there are currently no published data comparing intravenous infusion of propofol and ketamine without using volatile agents, we aimed to compare propofol and ketamine with a special emphasis on the incidence of pain, agitation, sedation, OCR, PONV, hemodynamics and consumption of anesthetics during strabismus surgery in children.

\section{Methods}

The study was performed in accordance with the most recent version of the Helsinki Declaration. Following approval from the institutional review board, written informed consent was obtained from the patients' families. The study group comprised 60 patients (American Society of Anesthesiologists [ASA] physical status $\leq$ I) at the Medical Faculty Ethical Committee of Gaziantep University from February through August 2009. The patients were aged 5 to 11 years and were from the day-surgery hospital of the department of Anesthesiology and Reanimation of Gaziantep University School of Medicine.

Patients excluded include: those with ASA physical status greater than I; those who were younger than 5 years or older than 11 years; those who had hypertension, psychiatric disorders, drug allergy, cardiovascular and clotting disorders, or peptic ulcers; or those whose families did not approve inclusion. Each patients' family was informed about the application. Patients were assigned to 1 of 2 study groups using a computer-generated random number table: Group ketamine (Group K, n = 30) and group propofol (Group P, n = 30). Ketamine was prepared with isotonic saline solution in unlabeled, impermeable, red $50 \mathrm{~mL}$ syringe. Propofol 1\% was prepared in unlabeled, impermeable, red $50 \mathrm{ml}$ syringe by an assistant for intravenous infusion.

After the patients had been taken to the surgery room, standard monitors including electrocardiography, mean arterial pressure, end-tidal $\mathrm{CO}_{2}$ and pulse oximetry were used. A 22-gauge cannula was inserted into a vein in the dorsum of the hand and saline was infused at a rate of $3 \mathrm{~mL} / \mathrm{kg} / \mathrm{h}$. No patient was premedicated. After preoxygenation, with $6 \mathrm{~L} / \mathrm{min} \mathrm{O}_{2}$, ketamine $1 \mathrm{mg} / \mathrm{kg}$ or propofol $3 \mathrm{mg} / \mathrm{kg}$ was given intravenously over 60 seconds by an anesthesiologist who was blind to the study. Both study solutions were prepared with isotonic saline solution in unlabeled, impermeable, red $50 \mathrm{~mL}$-syringe. After administrating fentanyl $1 \mu \mathrm{g} / \mathrm{kg}$ (fentanyl citrate 5 ampoules, $0.05 \mathrm{mg} / \mathrm{mL}$ );
B. Braun Melsungen AG, Berlin, Germany, and rocuronium bromide ([10 mg/mL]; Esmeron, Organon, Oss Holland) $0.5 \mathrm{mg} / \mathrm{kg}$ the patients were intubated. Anesthesia was maintained with intravenous infusion of ketamine or propofol with $50 \%$ oxygen and $50 \%$ air at $6 \mathrm{~L} / \mathrm{min}$. Patients in Group $\mathrm{K}$ were infused with ketamine hydrochloride (Ketalar; flacon, $50 \mathrm{mg} / \mathrm{mL}$, Ketalar ${ }^{\circledR}$; Pfizer Ortakoy-Istanbul) at a rate of 1-3 mg/kg/hr. Patients in Group P were infused intravenous propofol 6-9 mg/kg/hr (propofol 1\% fresenius, ampoules, $10 \mathrm{mg} / \mathrm{mL}$ ). All procedures were performed by the same surgeon. Before the traction of extraocular muscle began, the anesthesiologist had atropine immediately available. During the traction, the minimal heart rate was recorded. If the heart rate decreased from the basal heart rate by $20 \%$ beats/ min, ${ }^{13}$ the anesthesiologist asked the surgeon to release the extraocular muscle. He injected $0.01 \mathrm{mg} / \mathrm{kg}$ of atropine intravenously if bradycardia did not improve. The hemodynamics were recorded at the measurement times such as intubation, incision, operation, extubation, and postextubation periods. Neuromuscular blockade was reversed.

Recovery time was recorded as the time from the cessation of anesthetic infusion to obtaining verbal communication. The duration of surgery was accepted as the time from incision to complete hemostazis. The duration of mental orientation was recorded as the time taken from the end of intravenous anesthetic administration until responding to two orientation questions correctly (Where are you, who am I). Intravenous anesthetics were stopped 5 minutes before ending the operation and extubation was performed. The number of OCR, the consumption (mg) of ketamine and propofol during surgery was recorded. Postoperative nausea and vomiting were evaluated via numeric rank score (NRS): $0=$ no nausea 1 = vomiting once 2 = vomiting twice or more times. ${ }^{1}$ The evaluation of postoperative pain was performed using Faces Pain Scale (FPS), ${ }^{14}$ The FPS criteria used in this study were adapted from the FPS in order to make it possible to score on the widely accepted $0-10$ metric. ${ }^{14,15}$ Score the chosen face $0,2,4,6,8$, or 10 , counting left to right, so $0=$ no pain and $10=$ very much pain. In addition, Ramsay Sedation Score (RSS) was recorded on a numerical scale; 1 = anxiety and completely awake, 2 = completely awake, 3 = awake but drowsy, 4 = asleep but responsive to verbal commands, $5=$ asleep but responsive to tactile stimulus, and $6=$ asleep and not responsive to any stimulus. The preoperative and postoperative agitation (n, \%) were evaluated using an emergence agitation (behavior score) score $(1=$ sleeping, 2 = awake and calm, $3=$ irritable and crying, $4=$ inconsolable crying, $5=$ severe restlessness and 
disorientation purposelessly wanting to get out of the bed). ${ }^{16}$ As assessment of pain in younger children is difficult because of their limited understanding and verbal ablities, the evaluations of FPS, RSS, agitation score were performed with the help of children's parents during awakening. At the end of the operation, the satisfaction score of the surgeon was assessed according to the following numeric scale: $4=$ excellent (no complaint from surgeon); 3 = good (minor complaint without any need for supplemental anesthetics); 2 = moderate (due to the small motion of ocular globe back, which required supplemental anesthetics); 1 = unsuccessful (continuous ocular motion bothering the surgeon).

Two observers performed the data collection. The first observer performed the study. The second observer who was blind to the study, evaluated and recorded the data. Nausea and vomiting were treated with trimetobenzamid $\mathrm{HCl}\left(\right.$ Emedur $^{\circledR}$; $150 \mathrm{mg}$, Sanofi Synthelabo, ampoule). Nonopioid analgesic (metamizole) was given the patients who had FPS $>3$ after operation. Patients were discharged from the hospital within the first 4 hours after surgery if: their motor-mental functions had returned completely; they had no bleeding, nausea, or vomiting; and they could be fed.

\section{Statistical methods}

The results of the study were evaluated using the SPSS (Version 15.0 for Windows; SPSS Inc., Chicago, IL) statistical analysis package. Among the groups, age, weight, recovery time, heart rate, mean arterial blood pressure, the consumption of anesthetics and antiemetics, anesthesia time were compared using independent sample $t$-test. The incidence of oculocardiac reflex, postoperative agitation score, FPS, RSS the incidence of OCR, were compared using the Kruskal-Wallis test. Data were presented as mean \pm standard deviation (SD) or median (interquartile ranges) values or $\mathrm{n}(\%)$. Statistical significance was reported when the $P$ value was $<0.05$. After the power analysis according to the consumption of drug, we found the effect size $10($ alpha $=0.05$, actual power $=0.98$, delta $=4.0)$.

\section{Results}

The demographic characteristics (age, body mass index [BMI], gender), duration of surgery, duration of mental orientation, the number of the patients with agitation score $<4$ were similar between the groups (Table 1).

Recovery times in Group $\mathrm{K}$ was significantly shorter than in Group P $(P=0.008$, Table 1$)$. The consumption of ketamine and propofol were $53.3 \pm 19.3 \mathrm{mg}$ in Group $\mathrm{K}$ and $180.8 \pm 79.6 \mathrm{mg}$ in Group P, respectively. The consumption
Table I Demographic data: recovery times; duration of surgery; mental orientation; agitation score; consumption of anesthetics and antiemetics

\begin{tabular}{|c|c|c|c|}
\hline Demographic data & $\begin{array}{l}\text { Group K } \\
(n=30)\end{array}$ & $\begin{array}{l}\text { Group } P \\
(n=30)\end{array}$ & $P$ \\
\hline Age $(y r)$ & $7.7 \pm 3.1$ & $6.9 \pm 3.0$ & $\underline{0.2}$ \\
\hline Weight (kg) & $27.5 \pm 7.7$ & $24.8 \pm 7.0$ & $\underline{0.1}$ \\
\hline Body mass index $\left(\mathrm{kg} / \mathrm{m}^{2}\right)$ & $15.5 \pm 1.2$ & $15.3 \pm 1.5$ & 1.0 \\
\hline Gender (M/F) & $11 / 19$ & $12 / 18$ & $\underline{0.2}$ \\
\hline Recovery times (min) & $8.5 \pm 4.1 *$ & $1 \mathrm{I} .1 \pm 3.0$ & 0.008 \\
\hline Duration of surgery (min) & $55.8 \pm 19.3$ & $54.6 \pm 18.0$ & $\underline{0.1}$ \\
\hline $\begin{array}{l}\text { Duration of mental } \\
\text { orientation }(\mathrm{min})\end{array}$ & $38.8 \pm 8.0$ & $39.0 \pm 9.6$ & $\underline{0.9}$ \\
\hline $\begin{array}{l}\text { The patients with } \\
\text { agitation score }<4 \text { during } \\
\text { postoperative I-hour- }\end{array}$ & & & \\
\hline period (n) (\%) & $14(46)$ & II (36) & $\underline{0.3}$ \\
\hline $\begin{array}{l}\text { The consumption of } \\
\text { anesthetics }(\mathrm{mg})\end{array}$ & $53.6 \pm 19.6^{*}$ & $185.8 \pm 78.6$ & 0.0001 \\
\hline $\begin{array}{l}\text { The consumption of } \\
\text { antiemetic (Emedur, } \mathrm{mg} \text {, amp) }\end{array}$ & $5.0 \pm 27.3^{*}$ & $20.0 \pm 51.8$ & 0.004 \\
\hline
\end{tabular}

Notes: Data are presented as mean \pm SD or $n(\%), n=30$, NS: variation is not significant, $* \mathrm{P}<0.05$ when compared with Group $\mathrm{P}$

of anesthetic and antiemetic drugs (Emedur) in Group K were significantly lower than in Group P $(P=0.0001, P=0.004$, respectively; Table 1).

Nausea and vomiting was observed in 1 patient in Group K and in 4 patients in Group P. Postoperative NRS, sore throat, the number of patients required analgesic in postoperative 1-hour period, the satisfaction of surgeon during procedure were similar between the groups (Table 2).

The postoperative agitation score was significantly lower than the preoperative agitation score in Group $\mathrm{K}$ $(P=0.0001)$. The agitation score in Group $\mathrm{K}$ was significantly lower than in Group P during awakening $(P=0.005)$. The time of intraoperative OCR $(P=0.02)$ and FPS $(P=0.001)$ during awakening in Group $\mathrm{K}$ were significantly lower than in Group P. The RSS in Group K was significantly higher than in Group $\mathrm{P}$ during awakening $(P=0.01)$ and postoperative 60 th minute $(P=0.02$, Table 2$)$.

The heart rate in Group $\mathrm{K}$ was significantly higher than in Group P during intubation, incision, extubation, and after extubation periods $(P<0.05$, Figure 1$)$. The mean arterial blood pressure in Group $\mathrm{K}$ was significantly higher than in Group $\mathrm{P}$ during intubation, incision, operation, extubation, and after extubation periods ( $P<0.05$, Figure 2$)$. The increases in heart rate and mean arterial blood pressure disappeared in a few minutes without any treatment. Three patients in Group $\mathrm{P}$ were administered atropine $0.01 \mathrm{mg} / \mathrm{kg}$ to treat persistant bradycardia. 
Table 2 Scores and analgesic requirements of the groups

\begin{tabular}{llll}
\hline & Group K & Group P & P \\
\hline $\begin{array}{l}\text { The time of oculocardiac reflex } \\
\text { (OCR) (num) }\end{array}$ & $9 *$ & 25 & 0.02 \\
$\begin{array}{l}\text { Preoperative agitation score } \\
\text { Postoperative agitation score } \\
\text { during awakening }\end{array}$ & 5.0000 & 5.500 & 0.4 \\
$\begin{array}{l}\text { Faces Pain Scale during } \\
\text { awakening }\end{array}$ & $1.0000^{*+}$ & 1.0000 & 0.005 \\
$\begin{array}{l}\text { Ramsay Sedation Score } \\
\text { during awakening }\end{array}$ & $2.0000^{*}$ & 5.0000 & 0.00 I \\
$\begin{array}{l}\text { Ramsay Sedation Score at } \\
\text { postoperative 60th min }\end{array}$ & $5.0000^{*}$ & 5.0000 & 0.01 \\
$\begin{array}{l}\text { Postoperative (numeric rank } \\
\text { score) (50th median) }\end{array}$ & $4.0000^{*}$ & 3.0000 & 0.02 \\
$\begin{array}{l}\text { Postoperative sore } \\
\text { throat (n) (\%) }\end{array}$ & $0.4000^{*}$ & 2.0000 & 0.002 \\
$\begin{array}{l}\text { The analgesic requirement } \\
\text { during I-hour postoperative } \\
\text { period (n) (\%) }\end{array}$ & $8(26.6)$ & $12(40)$ & 0.2 \\
$\begin{array}{l}\text { The satisfaction score of } \\
\text { surgeon during procedure }\end{array}$ & $6(20)$ & $9(30)$ & 0.3 \\
\hline $\begin{array}{l}\text { Notes: } \\
\text { 1.0000 }\end{array}$ & 1.0000 & 0.7 \\
\hline
\end{tabular}

Notes: Data are presented as 50th (median) or num, $n=30$, NS: variation is not significant, $* P<0.05$ when compared with Group $P,{ }^{+} P<0.05$ when compared with the postoperative agitation score with preoperative values

\section{Discussion}

The main findings of this paper indicate that infusion of ketamine is more effective than intravenous infusion of propofol, in decreasing the consumption of anesthetics, antiemetics, the incidence of OCR, FPS, agitation score, and shortening the recovery time of children undergoing strabismus surgery. Furthermore, ketamine infusion provides a higher grade of sedation.
In this study, surgical procedures, which were performed by the same surgeon, were similar regarding pain stimuli. The surgical procedures, the duration of surgery, the number of muscles operated were also similar between the groups.

Strabismus surgery is performed to restore binocular single vision and for cosmetic reasons (extensively in childhood). There are some undesired effects of the surgery such as postoperative pain, ${ }^{3}$ anxiety, agitation, ${ }^{17} \mathrm{PONV}$, and OCR. ${ }^{13,18}$ These effects are the most frequent complications secondary to anesthesia, and leading causes for distress in patients recovering from general anesthesia. ${ }^{19,20}$ PONV adds to the expense of care due to the cost of anti-emetic drugs and prolonged stay in the recovery room. ${ }^{21}$

Propofol is an intravenous sedative-hypnotic agent with amnestic properties that causes loss of consciousness reliably. It provides rapid onset of action and dose-dependent sedative effect and a smooth recovery without dysphoria. It also has antiemetic and amnestic properties. Propofol inhibits $N$-methyl-D-aspartate (NMDA)-receptors in hippocampal neurons and this may have contributed to the positive effects on the mood state after operation. ${ }^{22}$ As there is a risk for accumulation in preterms and in the first two weeks of postnatal life, propofol clearance depends on postnatal age. ${ }^{23}$ Propofol infusion syndrome has to be kept in mind if propofol is used for anesthesia at doses greater than $4 \mathrm{mg} / \mathrm{kg} / \mathrm{h}$ of longer than 48 hours in especially pediatric patients. ${ }^{24}$

Ketamine, a recently launched S-isomer of ketamine, reportedly enhances analgesia greater than the racemic mixture. ${ }^{25}$ Ketamine has intrinsic analgesic and amnestic properties and protects airway reflexes. ${ }^{26,27}$ Ketamine activity has been suggested to be a result of the NMDA receptor

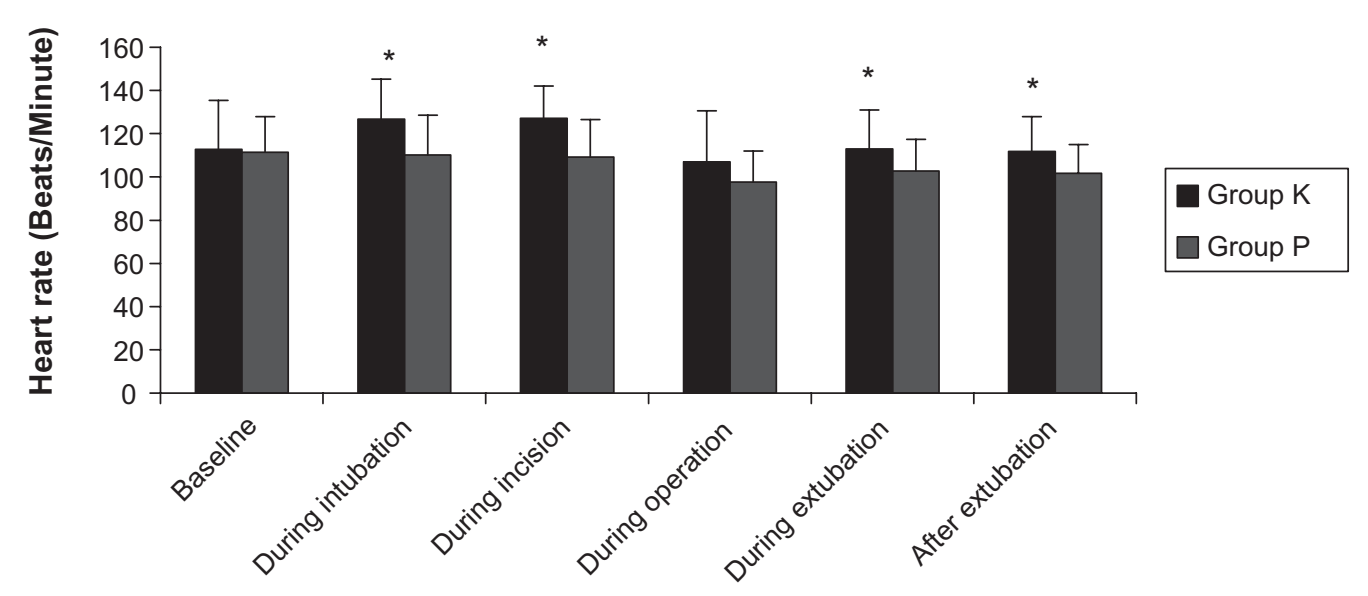

Periods

Figure I Heart rate of the groups.

Notes: $n=30$, ${ }^{*} p<0.05$, when Group K is compared with Group P. 


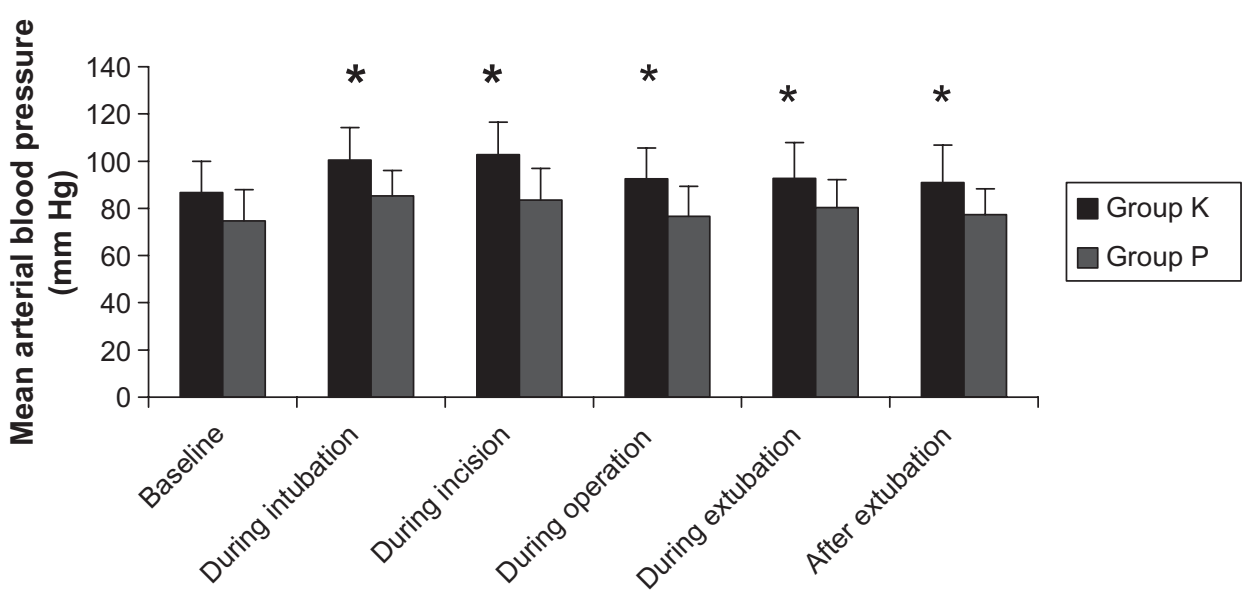

Periods

Figure 2 Mean arterial blood pressure of the groups.

Notes: $\mathrm{n}=30, * \mathrm{P}<0.05$, when compared the Group K with Group $\mathrm{P}$

antagonist property, ${ }^{28,29}$ furthermore, small-dose ketamine increases thalamic sensory output and arousal. ${ }^{30}$ Therefore, the administration of intravenous ketamine appears to be a safe and useful technique for monitored anesthesia care in the ambulatory setting. Although, experiments demonstrated that ketamine is a potent trigger for pathologic neuronal apoptosis this was demonstrated as a antihyperalgesic and antiproinflammatory drug. Such benefits were investigated in the pediatric population. ${ }^{31}$

Both propofol and ketamine provided safe and effective sedation for the short, painful procedures performed..$^{32}$ Painful procedures necessary in the care of children are increasing. ${ }^{2}$ Excessive pain can significantly lengthen the postoperative stay. Pain itself can also induce PONV. ${ }^{33}$ The pain level during awakening affects the patient's agitation score. This adverse effect has a direct negative effect on patient satisfaction. ${ }^{17}$ Although propofol produces dose-related sedation, amnesia, and anxiolysis, it is a poor analgesic and usually requires the use of an adjunctive analgesic agent. ${ }^{34}$ Contrary to our study, McDowall et $\mathrm{al}^{35}$ reported a decreased incidence of postanesthetic agitation with propofol, compared with sedation with ketamine or etomidate. This may be due to ketamine infusion in conjunction with low dose of fentanyl which could eliminate discomfort of children by increasing the sedation, decreasing the pain and thus agitation.

With titration of propofol or ketamine (without ocular motion, satisfactory muscle relaxation), the patients required a mean total dose of $185.8 \pm 78.6 \mathrm{mg}$ propofol and $153.6 \pm 19.6 \mathrm{mg}$ ketamine during procedure. Ketamine seems to be more cost effective. Some studies showed a significant longer recovery or extubation time when ketamine was administered. ${ }^{36,37}$ Moreover, it was reported that propofol has a pharmacokinetic profile leading to rapid induction and recovery times with minimal postoperative confusion. ${ }^{34}$ However, in this study, recovery time in Group K was significantly shorter than in Group P.

In the present study, the incidence of PONV and the consumption of antiemetics in Group P are significantly higher than in Group K although propofol, which provides hypnosis and amnesia, is antiemetic. ${ }^{38}$ When used solely as an induction drug, propofol has not been found to be beneficial in reducing the incidence of nausea or vomiting. The low consumption of ketamine may be the reason of low incidence of PONV as larger dosages of ketamine were associated with a clinically significant increase in PONV. ${ }^{33}$ Thorp et al ${ }^{39}$ reported that intravenous doses of ketamine-associated vomiting are not related to either the initial loading dose or the total dose but, the modest increase in receiving high cumulative doses $(>7 \mathrm{mg} / \mathrm{kg})$. Postoperative pain ${ }^{40}$ and use of opioid analgesia in the perioperative period ${ }^{41}$ may have contributed to this.

Three patients in Group $\mathrm{P}$ were administered atropine $0.01 \mathrm{mg} / \mathrm{kg}^{-1}$ to treat persistant bradycardia. The OCR was improved by releasing the traction first. Treatment with atropine $(0.01 \mathrm{mg} / \mathrm{kg})$ was only given in patients who had persistent OCR. In the current study, the patients administered with propofol seem to be more prone to develop pronounced OCR. Tramer et $\mathrm{al}^{8}$ revealed that propofol, despite the use of anticholinergics, substantially increases the incidence of OCR. Propofol has the potency to increase the incidence of bradycardia by a central sympatholytic effect and vagal 
stimulation. Ketamine seems to protect against the parasympathetic activation induced by OCR ${ }^{8}$ Choi et $\mathrm{al}^{42}$ reported that $1-2 \mathrm{mg} / \mathrm{kg}$ of ketamine for anesthetic induction results in a lower incidence of OCR than propofol in children undergoing strabismus surgery.

The heart rate and mean arterial blood pressure in Group K were significantly higher than in Group P during intubation, incision, extubation, and after extubation periods. Similar to Badrinath et $\mathrm{al},{ }^{43}$ heart rate and mean arterial blood pressure were within an acceptable range consequently no patient needed treatment. ${ }^{43}$ As signs of emotional trauma may be less in children treated as day cases than in those hospitalized for one or more nights, ${ }^{44}$ we discharged all patients during the four hours after surgery. The limitation of our study was the low number of subjects.

\section{Conclusion}

Our data suggests that intravenous infusion of ketamine as anesthetic with single dose of fentanyl as analgesic without volatiles may form a better combination of anesthesia than propofol in children undergoing strabismus surgery.

\section{Disclosures}

A combination of self funding and institutional funding has supported this work. The authors report no conflict of interest in this work.

\section{References}

1. Shende D, Das K. Comparative effects of intravenous ketorolac and pethidine on perioperative analgesia and postoperative nausea and vomiting (PONV) for paediatric strabismus surgery. Acta Anaesthesiol Scand. 1999;43(3):265-269.

2. Zeltzer L, Kellerman J, Ellenberg L, et al. Psychologic effects of illness in adolescence. II. Impact of illness in adolescents-crucial issues and coping styles. J Pediatr. 1980;97(1):132-138.

3. Cohen MM, Duncan PG, Pope WD, et al. A survey of 112,000 anaesthetics at one teaching hospital (1975-83). Can Anaesth Soc J. 1986; 33(1):22-31.

4. Drake R, Anderson BJ, Persson MA, et al. Impact of an antiemetic protocol on postoperative nausea and vomiting in children. Paediatr Anaesth. 2001;11(1):85-91.

5. Chhabra A, Pandey R, Khandelwal M, et al. Anesthetic techniques and postoperative emesis in pediatric strabismus surgery. Reg Anesth Pain Med. 2005;30(1):43-47.

6. Tramer MR. A rational approach to the control of postoperative nausea and vomiting: evidence from systematic reviews. Part I. Efficacy and harm of antiemetic interventions, and methodological issues. Acta Anaesthesiol Scand. 2001;45(1):4-13.

7. Hahnenkamp K, Honemann CW, Fischer LG, et al. Effect of different anaesthetic regimes on the oculocardiac reflex during paediatric strabismus surgery. Paediatr Anaesth. 2000;10(6):601-608.

8. Tramer MR, Moore RA, McQuay HJ. Propofol and bradycardia: causation, frequency and severity. Br J Anaesth. 1997;78(6):642-651.
9. Mirakhur RK, Jones CJ, Dundee JW, et al. I.m. or I.V. atropine or glycopyrrolate for the prevention of oculocardiac reflex in children undergoing squint surgery. Br J Anaesth. 1982;54(10):1059-1063.

10. Wilhelm S, Standl T. [Does propofol have advantages over isoflurane for sufentanil supplemented anesthesia in children for strabismus surgery?]. Anasthesiol Intensivmed Notfallmed Schmerzther. 1996;31(7):414-419.

11. Blanc VF. Ventilation and the oculocardiac reflex. Anaesthesia. 1987;42(3):324-326.

12. Ohmi G, Hosohata J, Okada AA, et al. Strabismus surgery using the intraoperative adjustable suture method under anesthesia with propofol. Jpn J Ophthalmol. 1999;43(6):522-525.

13. Stump M, Arnold RW. Iris color alone does not predict susceptibility to the oculocardiac reflex in strabismus surgery. Binocul Vis Strabismus $Q$. 1999;14(2):111-116.

14. Bieri D, Reeve RA, Champion GD, et al. The Faces Pain Scale for the self-assessment of the severity of pain experienced by children: development, initial validation, and preliminary investigation for ratio scale properties. Pain. 1990;41(2):139-150.

15. Suraseranivongse $\mathrm{S}$, Montapaneewat T, Manon J, et al. Cross-validation of a self-report scale for postoperative pain in school-aged children. J Med Assoc Thai. 2005;88(3):412-418.

16. Vishne T, Amiaz R, Grunhaus L. Promethazine for the treatment of agitation after electroconvulsive therapy: a case series. $J$ Ect. 2005;21(2):118-121.

17. Meeks GR, Waller GA, Meydrech EF, et al. Unscheduled hospital admission following ambulatory gynecologic surgery. Obstet Gynecol. 1992;80(3 Pt 1):446-450.

18. Lerman J, Eustis S, Smith DR. Effect of droperidol pretreatment on postanesthetic vomiting in children undergoing strabismus surgery. Anesthesiology. 1986;65(3):322-325.

19. Janicki PK. Cytochrome P450 2D6 metabolism and 5-hydroxytryptamine type 3 receptor antagonists for postoperative nausea and vomiting. Med Sci Monit. 2005;11(10):RA322-RA328.

20. Apfel CC, Korttila K, Abdalla M, et al. A factorial trial of six interventions for the prevention of postoperative nausea and vomiting. $N$ Engl J Med. 2004;350(24):2441-2451.

21. Watcha MF. The cost-effective management of postoperative nausea and vomiting. Anesthesiology. 2000;92(4):931-933.

22. Orser BA, Bertlik M, Wang LY, et al. Inhibition by propofol (2,6 diisopropylphenol) of the N-methyl-D-aspartate subtype of glutamate receptor in cultured hippocampal neurones. Br J Pharmacol. 1995;116(2):1761-1768.

23. Allegaert K, de Hoon J, Naulaers G, et al. Neonatal clinical pharmacology: recent observations of relevance for anaesthesiologists. Acta Anaesthesiol Belg. 2008;59(4):283-288.

24. Fudickar A, Bein B. Propofol infusion syndrome: update of clinical manifestation and pathophysiology. Minerva Anestesiol. 2009;75(5):339-344.

25. White PF, Schuttler J, Shafer A, et al. Comparative pharmacology of the ketamine isomers. Studies in volunteers. Br J Anaesth. 1985;57(2):197-203.

26. White PF, Way WL, Trevor AJ. Ketamine - its pharmacology and therapeutic uses. Anesthesiology. 1982;56(2):119-136.

27. Green SM, Johnson NE. Ketamine sedation for pediatric procedures: Part 2, Review and implications. Ann Emerg Med. 1990;19(9):1033-1046.

28. Krystal JH, Karper LP, Seibyl JP, et al. Subanesthetic effects of the noncompetitive NMDA antagonist, ketamine, in humans. Psychotomimetic, perceptual, cognitive, and neuroendocrine responses. Arch Gen Psychiatry. 1994;51(3):199-214.

29. Suzuki M, Tsueda K, Lansing PS, et al. Small-dose ketamine enhances morphine-induced analgesia after outpatient surgery. Anesth Analg. 1999;89(1):98-103. 
30. Carlsson M, Carlsson A. Schizophrenia: a subcortical neurotransmitter imbalance syndrome? Schizophr Bull. 1990;16(3):425-432.

31. De Kock M. [Ketamine for paediatric anaesthesia: useful, fool or ?]. Ann Fr Anesth Reanim. 2007;26(6):524-528.

32. Seigler RS, Avant MG, Gwyn DR, et al. A comparison of propofol and ketamine/midazolam for intravenous sedation of children. Pediatr Crit Care Med. 2001;2(1):20-23.

33. Chung F, Mezei G. Factors contributing to a prolonged stay after ambulatory surgery. Anesth Analg. 1999;89(6):1352-1359.

34. Smith I, White PF, Nathanson M, et al. Propofol. An update on its clinical use. Anesthesiology. 1994;81(4):1005-1043.

35. McDowall RH, Scher CS, Barst SM. Total intravenous anesthesia for children undergoing brief diagnostic or therapeutic procedures. $J$ Clin Anesth. 1995;7(4):273-280.

36. St Pierre M, Kessebohm K, Schmid M, et al. [Recovery from anaesthesia and incidence and intensity of postoperative nausea and vomiting following a total intravenous anaesthesia (TIVA) with S-(+)ketamine/propofol compared to alfentanil/propofol]. Anaesthesist. 2002;51(12):973-979.

37. Lawrence LM, Wright SW. Sedation of pediatric patients for minor laceration repair: effect on length of emergency department stay and patient charges. Pediatr Emerg Care. 1998;14(6):393-395.
38. Raftery S, Sherry E. Total intravenous anaesthesia with propofol and alfentanil protects against postoperative nausea and vomiting. Can J Anaesth. 1992;39(1):37-40.

39. Thorp AW, Brown L, Green SM. Ketamine-associated vomiting: is it dose-related? Pediatr Emerg Care. 2009;25(1):15-18.

40. Andersen R, Krohg K. Pain as a major cause of postoperative nausea. Can Anaesth Soc J. 1976;23(4):366-369.

41. Mendel HG, Guarnieri KM, Sundt LM, et al. The effects of ketorolac and fentanyl on postoperative vomiting and analgesic requirements in children undergoing strabismus surgery. Anesth Analg. 1995;80(6):1129-1133.

42. Choi SH, Lee SJ, Kim SH, et al. Single bolus of intravenous ketamine for anesthetic induction decreases oculocardiac reflex in children undergoing strabismus surgery. Acta Anaesthesiol Scand. 2007;51(6):759-762.

43. Badrinath S, Avramov MN, Shadrick M, et al. The use of a ketaminepropofol combination during monitored anesthesia care. Anesth Analg. 2000;90(4):858-862.

44. Hadaway EG, Ingram RM, Traynar MJ. Day case surgery for strabismus in children. Trans Ophthalmol Soc UK. 1977;97(1):23-25.
Clinical Ophthalmology

\section{Publish your work in this journal}

Clinical Ophthalmology is an international, peer-reviewed journal covering all subspecialties within ophthalmology. Key topics include: Optometry; Visual science; Pharmacology and drug therapy in eye diseases; Basic Sciences; Primary and Secondary eye care; Patien Safety and Quality of Care Improvements. This journal is indexed on

Submit your manuscript here: http://www.dovepress.com/clinical-ophthalmology-journal

\section{Dovepress}

PubMed Central and CAS, and is the official journal of The Society of Clinical Ophthalmology (SCO). The manuscript management system is completely online and includes a very quick and fair peer-review system, which is all easy to use. Visit http://www.dovepress.com/ testimonials.php to read real quotes from published authors. 